\title{
ANALISIS FAKTOR-FAKTOR YANG MEMPENGARUHI AUDIT DELAY (STUDI EMPIRIS PADA PERUSAHAAN PROPERTY DAN REAL ESTATE YANG TERDAFTAR DI BURSA EFEK INDONESIA)
}

\author{
Alther Gabriel Liwe ${ }^{1}$, Hendrik Manossoh ${ }^{2}$, Lidia M. Mawikere ${ }^{3}$ \\ ${ }^{1,2,3}$ Jurusan Akuntansi, Fakultas Ekonomi dan Bisnis, Universitas Sam Ratulangi, Jl. Kampus Bahu, Manado, \\ 95115, Indonesia \\ E-mail : alther.liwe@gmail.com
}

\begin{abstract}
Audit delay is the length of time from a company's fiscal year end to the date of the auditor's report. This research aims to determine the effect of firm size, profitability, and solvability on audit delay in property and real estate company which are listed on the Indonesia Stock Exchange (IDX) period 2012-2016. The samples consist of 38 property and real estates company. The data analysis technique used was multiple linear regression analysis. The results showed that partial firm size does not have any significant effect on audit delay, profitability have significant effect on audit delay, and solvability does not have any significant effect on audit delay, while simultaneously firm size, profitability, and solvability have significant effect on audit delay.
\end{abstract}

Keywords: Audit Delay, Firm Size, Profitability, Solvability

\section{PENDAHULUAN}

Perkembangan perekonomian Indonesia tidak lepas dari pertumbuhan dan kemajuan perusahaan-perusahaan yang ada di Indonesia. Salah satu indikator yang membuat perusahaan semakin berkembang dan dikenal secara luas yaitu dengan go public. Perusahaan go public harus terdaftar di Bursa Efek Indonesia (BEI) dengan beberapa ketentuan yang sudah diatur. Setiap perusahaan yang telah terdaftar di BEI diwajibkan untuk menyampaikan laporan keuangan yang telah disusun sesuai dengan Standar Akuntansi Keuangan dan telah diaudit oleh akuntan publik yang terdaftar di Badan Pengawas Pasar Modal dan Lembaga keuangan (Apriliane, 2015).

Penyampaian laporan keuangan tidak lepas dari proses audit hingga laporan keuangan dan laporan auditor independen dapat di publikasikan kepada pihak eksternal. Periode waktu antara tanggal tahun fiskal laporan keuangan dengan tanggal penandatanganan laporan audit independen mengindikasikan tentang lamanya waktu penyelesaian pekerjaan audit yang dilakukan oleh auditor atau yang sering disebut dengan istilah audit delay. Menurut Wardan dan Mushawir (2016) Audit delay adalah lamanya waktu penyelesaian audit diukur dari berakhirnya tahun fiskal sampai dengan tanggal ditandatanganinya laporan audit (tanggal opini). Dengan kata lain, audit delay adalah lamanya waktu dari tanggal tutup tahun fiskal perusahaan sampai dengan tanggal laporan auditor.

Ada beberapa faktor yang kemungkinan dapat mempengaruhi audit delay pada suatu perusahaan. Diantaranya adalah ukuran perusahaan, profitabilitas, solvabilitas, dan beberapa faktor lainnya. Menurut Dyer dan McHugh (1975) mengenai ukuran perusahaan, perusahaan besar lebih konsisten untuk tepat waktu dibandingkan perusahaan kecil dalam menginformasikan laporan keuangannya. Pengaruh ini ditunjukkan dengan semakin besar nilai aktiva perusahaan maka semakin pendek audit delay dan sebaliknya. Hal ini disebabkan karena perusahaan besar biasanya memilki sistem pengendalian internal yang baik, sehingga dapat mengurangi tingkat kesalahan dalam penyusunan laporan keuangan yang memudahkan auditor dalam melakukan audit laporan keuangan. 
Selain itu juga tingkat profitabilitas perusahaan diperkirakan mempengaruhi audit delay. Profitabilitas adalah kemampuan perusahaan dalam menghasilkan laba selama periode tertentu. Semakin tinggi tingkat profitabilitas maka keinginan perusahaan untuk mempublikasikan laporan keuangan juga akan semakin cepat, dikarenakan akan memberikan nilai tambah bagi perusahaan kepada investor. Profitabilitas perusahaan dilihat dari laporan laba rugi perusahaan (income statement) yang menunjukkan laporan hasil kinerja selama periode tertentu.

Selain profitabilitas tingkat kewajiban perusahaan menjadi tolak ukur terhadap audit delay. Menurut Apriyana (2017) solvabilitas merupakan kemampuan suatu perusahaan untuk memenuhi seluruh kewajiban finansialnya pada saat perusahaan dilikuidasi. Solvabilitas dapat diukur dengan membuat perbandingan utang terhadap aktiva atau ekuitas. Proses pengauditan utang relatif membutuhkan waktu yang lebih lama dibandingkan pengauditan ekuitas, maka dari itu diperkirakan tingkat solvabilitas yang tinggi akan menyebabkan semakin lama audit delay.

Berdasarkan uraian masalah dan penelitian sebelumnya, penulis ingin melukukan penelitian yang berkaitan dengan Audit delay dikarenakan setiap perusahaan yang terdaftar di Bursa Efek Indonesia memiliki rentang waktu Audit delay yang beragam, serta kebutuhan akan laporan keuangan oleh investor dan pihak yang berkepentingan lainnya agar dapat dipublikasikan secara cepat. Ada beberapa faktor yang diperkirakan mempengaruhi Audit delay yang akan diangkat dalam penelitian ini, yaitu Ukuran perusahaan, Profitabilitas, dan Solvabilitas. Faktor-faktor tersebut dipilih karena sangat berkaitan langsung dengan laporan keuangan perusahaan. Objek dalam penelitian ini akan difokuskan pada Perusahaan Property dan Real Estate yang terdaftar di BEI, karena berdasarkan penelitian terdahulu faktor-faktor yang digunakan dalam penelitian ini mempunyai pengaruh terhadap Audit delay. Maka judul dalam penelitian ini yaitu "Analisis Faktor-Faktor yang Mempengaruhi Audit Delay (Studi Empiris pada Perusahaan Property dan Real Estate yang Terdaftar di Bursa Efek Indonesia)".

Tujuan penelitian yang ingin dicapai dalam penelitian ini sebagai berikut.

1. Untuk mengetahui pengaruh ukuran perusahaan terhadap audit delay.

2. Untuk mengetahui pengaruh profitabilitas terhadap audit delay.

3. Untuk mengetahui pengaruh solvabilitas terhadap audit delay.

\section{TINJAUAN PUSTAKA}

\subsection{Audit Delay}

Menurut Ashton et al (1987) "Audit delay is the length of time from a company's fiscal year end to the date of the auditor's report". Audit delay adalah lamanya waktu dari akhir tahun fiskal perusahaan sampai tanggal laporan audit. Ketepatan waktu dalam penyampaian laporan keuangan yang telah diaudit merupakan hal yang penting, khususnya untuk perusahaan-perusahaan publik yang menggunakan pasar modal sebagai salah satu sumber pendanaan. Menurut Lawrence \& Briyan (1998) Audit Delay adalah lamanya hari yang dibutuhkan auditor untuk menyelesaikan pekerjaan auditnya, yang diukur dari tanggal penutupan tahun buku hingga tanggal diterbitkannya laporan keuangan audit. Audt delay dapat dirumuskan sebagai berikut:

$$
\text { Audit Delay }=\text { Tanggal Laporan Audit }- \text { Tanggal Laporan Keuangan }
$$

\subsection{Ukuran Perusahaan}

Menurut Ferry \& Jones (1979) ukuran perusahaan adalah suatu skala dimana dapat diklasifikasikan besar kecilnya perusahaan menurut berbagai cara, antara lain: total aktiva, penjualan, log size, nilai pasar saham, kapitalisasi pasar, dan lain-lain yang semuanya berkorelasi tinggi. Semakin besar total aktiva, penjualan, log size, nilai pasar saham, dan kapitalisasi pasar maka semakin besar pula ukuran perusahaan tersebut. 
Ardianti (2013) menjelaskan ukuran perusahaan dapat dilihat dari kepemilikan jumlah total aset, jumlah total penjualan tiap periode, jumlah karyawan, dan lain-lain. Semakin besar nilainya maka akan semakin besar pula ukuran perusahaan. Dalam penelitian ini ukuran perusahaan diukur menggunakan total aset yang terdapat dalam laporan keuangan khususnya laporan posisi keuangan (neraca). Ukuran perusahaan dapat dirumuskan sebagai berikut:

$$
\text { Ukuran Perusahaan = Log Natural } \text { (Total aset) }
$$

\subsection{Profitabilitas}

Menurut Kasmir (2016:196) rasio profitabilitas yakni rasio yang menilai kemampuan perusahaan dalam mencari keuntungan atau laba dalam suatu periode tertentu. Profitabilitas merupakan rasio yang digunakan untuk mengukur kemampuan perusahaan dalam menghasilkan keuntungan bagi perusahaan yang menunjukkan tingkat keefektivan dan menilai sejauh mana kinerja perusahaan dalam menghasilkan keuntungan bagi investor. Semakin baik rasio profitabilitas maka semakin baik menggambarkan kemampuan tingginya perolehan keuntungan perusahaan.

Profitabilitas merupakan hasil dari sejumlah besar kebijakan dan keputusan manajemen dalam menggunakan sumber dana perusahaan. Dalam penelitian ini perhitungan profitabilitas diukur dengan Return on Asset Rasio (ROA), rasio ini mengukur kemampuan perusahaan menghasilkan laba berdasarkan tingkat asset tertentu. Menurut Prameswari dan Yustrianthe (2015) ROA merupakan perbandingan antara jumlah laba yang dihasilkan terhadap asset yang digunakan, sehingga menunjukkan jumlah perusahaan yang mampu untuk menghasilkan laba dari sumber daya (asset) yang dimiliki. Profitabilitas dapat dirumuskan sebagai berikut:

Profitabilitas $($ ROA $)=$ Laba bersih / Total aset x $100 \%$

\subsection{Solvabilitas}

Menurut Kasmir (2016:150) rasio solvabilitas atau leverage ratio merupakan rasio yang digunakan untuk mengukur sejauh mana aktivitas perusahaan dibiayai dengan hutang. Fahmi (2014:59) bahwa rasio solvabilitas yaitu rasio yang menunjukkan bagaimana perusahaan mampu untuk mengelola hutangnya dalam rangka memperoleh keuntungan dan juga mampu untuk melunasi kembali hutangnya. Perusahaan yang tidak solvabel adalah perusahaan yang utang totalnya lebih besar dibandingkan total asetnya. Semakin tinggi rasio solvabilitas maka semakin tinggi pula resiko kerugian atau kesulitan keuangan yang dihadapi.

Solvabilitas dapat diukur dengan menggunkan total aset perusahaan dan total ekuitas perusahaan. Dalam penelitian ini yang menjadi tolak ukur Solvabilitas diukur dengan Total Debt to Total Asset rasio (TDTA), rasio ini membandingkan jumlah utang (baik jangka pendek ataupun jangka panjang) dengan jumlah aset (total asset). Solvabilitas dapat dirumuskan sebagai berikut:

Solvabilitas $($ TDTA $)=$ Total utang/ Total aset $\times 100 \%$

\subsection{Profitabilitas}

Pada bagian ini akan dijelaskan mengenai pengembangan hipotesis-hipotesis penelitian dengan dasar penelitian-penelitian terdahulu.Terdapat empat hipotesis penelitian yang akan dijabarkan sebagai berikut:

H1: Ukuran perusahaan berpengaruh signifikan terhadap audit delay

$\mathrm{H} 2$ : Profitabilitas berpengaruh signifikan terhadap audit delay.

H3: Solvabilitas berpengaruh signifikan terhadap audit delay.

H4: Ukuran perusahaan, Profitabilitas, dan Solvabilitas berpengaruh signifikan terhadap audit delay. 


\section{METODE PENELITIAN}

\subsection{Jenis dan Sumber Data}

Penelitian ini menganalisis data kuantitatif, yaitu data yang berbentuk angka diperoleh dari laporan keuangan berupa nilai aktiva, kewajiban, laba bersih, dan perhitungan waktu audit. Sumber data dalam penelitian ini adalah data sekunder yang bersumber dari dokumentasi perusahaan, yaitu laporan keuangan tahunan atau annual report perusahaan property dan real estate yang terdaftar di Bursa Efek Indonesia (BEI).

\subsection{Sampel dan Teknik Pengambilan Sampel}

Sampel yaitu sebagian dari populasi atau dalam istilah matematik dapat disebut sebagai himpunan bagian atau subset dari populasi. Metode sampel yang diterapkan adalah metode purposive sampling yang merupakan teknik pengambilan data secara non probabilitas (nonprobability sampling). Purposive sampling yaitu pemilihan sampel secara tidak acak yang diperoleh dengan menggunakan pertimbangan tertentu. Dalam penelitian ini perusahaan diseleksi berdasarkan kriteria- kriteria sebagai berikut.

1) Perusahaan property dan real estate yang telah mempublikasikan laporan keuangan tahunan 5 tahun berturut-turut, dari tahun 2012 sampai dengan tahun 2016.

2) Perusahaan property dan real estate yang telah mempublikasikan laporan keuangan tahunan secara lengkap.

Perusahaan yang terdaftar di Bursa Efek Indonesia pada tahun 2017 yaitu 48 perusahaan. Sampel dalam penelitian ini ditentukan berdasarkan kriteria-kriteria di atas. Hasil pemilihan sampel yaitu sebagai berikut; perusahaan yang telah mempublikasikan laporan keuangan tahunan 5 tahun berturut-turut dari tahun 2012 sampai dengan tahun 2016 yaitu 40 perusahaan, dan yang sudah mempublikasikan laporan keuangan tahunan secara lengkap yaitu 38 perusahaan. Jadi sampel yang dapat digunakan yaitu 38 perusahaan property dan real estate yang terdaftar di Bursa Efek Indonesia (BEI).

\subsection{Metode Analisis}

Analisis data berisi pengujian data perusahaan property dan real estate yang terdaftar di Bursa Efek Indonesia (BEI). Analisis data yang digunakan dalam penelitian ini yaitu Uji Regresi Linear Berganda. Uji Regresi Linear Berganda yaitu adalah hubungan secara linear antara dua atau lebih variabel independen (X) dengan variabel dependen (Y). Pengujian regresi linear berganda di awali dengan Uji Asumsi Klasik. Dengan adanya pengujian ini diharapkan agar model regresi yang diperoleh dapat dipertanggungjawabkan. Oleh karena itu, perlu dilakukan uji asumsi klasik yang terdiri dari Uji Normalitas, Uji Multikolinearitas, Uji Heteroskedastisitas, dan Uji autokorelasi sebelum melakukan Uji Regresi dan Uji Hipotesis.

\section{HASIL ANALISIS DAN PEMBAHASAN}

\subsection{Hasil Analisis}

\subsubsection{Uji Asumsi Klasik}

Sebelum melakukan analisis regresi linier berganda, data diuji terlebih dahulu dengan uji asumsi klasik sebagai syarat melakukan pengujian. Uji asumsi klasik yang digunakan yaitu Uji Normalitas, Uji Multikolinearitas, Uji Hetoroskadektisitas, dan Uji Autokorelasi. Berikut hasil uji asumsi klasik dalam penelitian ini.

a. Uji Normaliatas

Uji normalitas dilakukan untuk mengetahui apakah model regresi variabel dependen dan independen atau keduanya berdistribusi normal atau tidak. Model regresi yang baik adalah yang berdistribusi nomal atau mendekati normal. Pengujian normalitas dilakukan menggunakan analisa Kolmogorov-Smirnov dengan dasar pengambilan keputusan jika nilai signifikansi > 0,05 maka data tersebut berdistribusi normal. Dari hasil uji normalitas diperoleh hasil sebagai berikut. 


\begin{tabular}{|ll|r|}
\hline \multicolumn{2}{|c|}{ One-Sample Kolmogorov-Smirnov Test } \\
\hline $\mathrm{N}$ & $\begin{array}{c}\text { Unstandardized } \\
\text { Residual }\end{array}$ \\
Normal Parameters ${ }^{\mathrm{a}, \mathrm{b}}$ & Mean & 38 \\
& Std. Deviation & .0000000 \\
Most Extreme Differences & Absolute & 15.36764279 \\
& Positive & .124 \\
& Negative & .124 \\
Test Statistic & & -.083 \\
Asymp. Sig. (2-tailed) & & .124 \\
\hline
\end{tabular}

a. Test distribution is Normal.

b. Calculated from data.

c. Lilliefors Significance Correction.

(Sumber: Data hasil olahan SPSS, 2018)

Berdasarkan hasil uji normalitas diperoleh nilai signifikansi sebesar 0,144 > 0,05. Jadi dapat disimpulkan data berdistribusi normal karena nilai signifikansi > 0,05

b. Uji Multikolinearitas

Uji Multikolineritas bertujuan untuk mengetahui apakah variabel bebas (independen) saling berkorelasi atau tidak. Model regresi yang baik seharusnya tidak terjadi korelasi antara variabel bebas. Multikolineritas dapat dideteksi dengan menggunakan nilai tolerance dan nilai VIF (Variance Inflation Factor). Data dikatakan tidak terdapat multikolineritas adalah apabila nilai tolerance $>0,1$ dan nilai VIF $<10$. Dari hasil uji multikolinerias diperoleh hasil untuk masing-masing variabel sebagai berikut.

\begin{tabular}{|cl|r|c|}
\hline \multicolumn{2}{|c|}{ Coefficients $^{\mathbf{a}}$} \\
\cline { 3 - 4 } Model & \multicolumn{2}{c|}{ Collinearity Statistics } \\
\cline { 3 - 4 } & & Tolerance & \multicolumn{1}{c|}{ VIF } \\
\hline & (Constant) & .962 & \\
& UKURAN PERUSAHAAN & .991 & 1.040 \\
& PROFITABILITAS & .953 & 1.010 \\
& SOLVABILITAS & & 1.049 \\
\hline
\end{tabular}

a. Dependent Variable: AUDIT DELAY

(Sumber: Data hasil olahan SPSS, 2018)

Berdasarkan hasil uji multikolinearitas diperoleh Ukuran Perusahaan nilai tolerance $0,962>0,1$ dan nilai VIF $1,040<10$, Profitabilitas nilai tolerance $0,962>0,1$ dan nilai VIF $1,010<10$, dan Solvabilitas nilai tolerance 0,953 > 0,1 dan nilai VIF 1,049 < 10. Jadi dapat disimpukan bahwa tidak ada multikolineritas antara variabel independen dalam model regresi karena semua variabel independen memiliki nilai tolerance $>0,1$ dan nilai VIF $<10$.

c. Uji Heterokedastisitas

Uji Heteroskedastisitas bertujuan untuk menguji apakah dalam model regresi terjadi ketidaksamaan variance dari residual satu pengamatan ke pengamatan yang lain. Model regresi yang baik adalah apabila terdapat kesamaan atau tidak terjadi heteroskedastisitas. Untuk mendeteksi terjadi tidaknya heteroskedastisitas pada model regresi digunakan uji glejser dengan dasar pengambilan keputusan jika nilai signifikansi > 0,05 maka tidak terdapat heteroskedastisitas dalam model regresi. Dari hasil uji heteroskadektisitas diperoleh hasil sebagai berikut.

\section{Coefficients $^{\mathrm{a}}$}

\begin{tabular}{|cl|r|}
\hline Model & & \multicolumn{1}{|c|}{ Sig. } \\
\hline 1 & (Constant) & .392 \\
& UKURAN PERUSAHAAN & .152 \\
& PROFITABILITAS & .509 \\
& SOLVABILITAS & .810 \\
\hline
\end{tabular}

a. Dependent Variable: AUDIT DELAY (RES_2)

(Sumber: Data hasil olahan SPSS, 2018) 
Berdasarkan hasil uji glesjer diperoleh Ukuran Perusahaan nilai signifikansi 0,152 > 0,05, Profitabilitas nilai signifikansi $0,509>0,05$, dan Solvabilitas nilai signifikansi $0,810>$ 0,05 . Jadi dapat disimpukan bahwa tidak terjadi masalah heteroskedastisitas pada model regresi karena signifikansi (sig.) semua variabel independen $>0,05$.

d. Uji Autokorelasi

Uji Autokorelasi bertujuan untuk menguji apakah dalam model regresi linier ada korelasi antara periode sekarang dengan periode sebelumnya. Model regresi yang baik adalah yang tidak terjadi autokorelasi. Dalam penelitian ini, uji autokorelasi dilakukan dengan uji Durbun Watson $(D W)$. Cara mendeteksi apakah model yang digunakan mengalami gejala autokorelasi adalah dengan melihat nilai DW dibandingkan dengan nilai dL dan dU. Table Durbin Watson untuk $\mathrm{n}=38$ dan $\mathrm{k}=4$ diperoleh nilai batas bawah (dL) 1,261 dan nilai batas atas (dU) 1,722. Dari hasil uji autokorelasi diperoleh hasil sebagai berikut.

Model Summary

\begin{tabular}{|l|r|r|r|r|r|}
\hline Model & $\mathrm{R}$ & R Square & $\begin{array}{c}\text { Adjusted R } \\
\text { Square }\end{array}$ & $\begin{array}{c}\text { Std. Error of the } \\
\text { Estimate }\end{array}$ & Durbin-Watson \\
\hline 1 & $.267^{2}$ & .071 & -.011 & 11.62486 & 2.046 \\
\hline
\end{tabular}

a. Predictors: (Constant), SOLVABILITAS, PROFITABILITAS, UKURAN PERUSAHAAN

b. Dependent Variable: AUDIT DELAY (RES_2)

(Sumber: Data hasil olahan SPSS, 2018)

Berdasarkan hasil uji autokorelasi diperoleh nilai DW 2,046 maka nilai 1,261 < 2,046 $<2,739$. Jadi dapat disimpukan bahwa tidak terjadi autokorelasi karena $\mathrm{dU}<\mathrm{DW}<4$-dU.

\subsubsection{Uji Regresi Linear Berganda}

Uji regresi linear berganda dalam penelitian ini digunakan untuk mengetahui bagaimana pengaruh ukuran perusahaan, profitabilitas, dan solvabilitas terhadap audit delay pada perusahaan Property dan Real Estate yang terdaftar di Bursa Efek Indonesia. Uji regresi linear berganda dapat dilakukan karena, data penelitian telah layak digunakan dan telah memenuhi persyarat uji asumsi klasik. Dari hasil uji regresi linear berganda diperoleh hasil sebagai berikut.

\begin{tabular}{|c|c|c|c|c|c|c|}
\hline \multicolumn{7}{|c|}{ Coefficients $^{a}$} \\
\hline \multirow{2}{*}{\multicolumn{2}{|c|}{ Model }} & \multicolumn{2}{|c|}{ Unstandardized Coefficients } & \multirow{2}{*}{$\begin{array}{c}\text { Standardized } \\
\text { Coefficients } \\
\text { Beta }\end{array}$} & \multirow[b]{2}{*}{$\mathrm{t}$} & \multirow[b]{2}{*}{ Sig. } \\
\hline & & $\mathrm{B}$ & Std. Error & & & \\
\hline \multirow[t]{4}{*}{1} & (Constant) & 57.883 & 29.733 & & 1.947 & .060 \\
\hline & UKURAN PERUSAHAAN & .937 & 1.024 & .139 & .915 & .366 \\
\hline & PROFITABILITAS & -1.727 & .548 & -.472 & -3.153 & .003 \\
\hline & SOLVABILITAS & .169 & .184 & .140 & .919 & .365 \\
\hline
\end{tabular}

a. Dependent Variable: AUDIT DELAY

(Sumber: Data hasil olahan SPSS, 2018)

Dari hasil uji regresi linear berganda dapat diperoleh persamaan regresi linier berganda sebagai berikut. berikut.

$\mathrm{Y}=57,883+0,937 \mathrm{X} 1+(-1,727) \mathrm{X} 2+0,169 \mathrm{X} 3+\mathrm{e}$

Hasil persamaan regresi ini secara keseluruhan menunjukkan hasil interpretasi sebagai

1. Konstanta $(\alpha)$ sebesar 57,883 menyatakan bahwa jika tidak terdapat nilai ukuran perusahaan (X1), profitabilitas (X2), dan solvabilitas (X2) atau sama dengan nol maka audit delay (Y) nilainya adalah 57,883.

2. Koefisien regresi untuk ukuran perusahaan $\left(\beta_{1}\right)$ sebesar 0,937 artinya, jika variabel lainnya tetap dan ukuran perusahaan mengalami kenaikan 1 (Log Natural) maka audit delay akan mengalami pertambahan sebesar 0,937 . Koefisien regresi bernilai positif artinya terjadi hubungan searah antara ukuran perusahaan dan audit delay, semakin tinggi ukuran perusahaan maka jangka waktu audit delay semakin lama. 
3. Koefisien regresi untuk profitabilitas $\left(\beta_{2}\right)$ sebesar $-1,727$ artinya, jika variabel lainnya tetap dan profitabilitas mengalami kenaikan $1 \%$ maka audit delay akan mengalami penurunan sebesar 1,727 hari. Koefisien regresi bernilai negatif artinya terjadi hubungan berlawanan arah antara profitabilitas dan audit delay, semakin tinggi profitabilitas maka jangka waktu audit delay semakin cepat.

4. Koefisien regresi untuk solvabilitas $\left(\beta_{3}\right)$ sebesar 0,169 artinya, jika variabel lainnya tetap dan solvabilitas mengalami kenaikan $1 \%$ maka audit delay akan mengalami kenaikan sebesar 0,169 hari. Koefisien regresi bernilai positif artinya terjadi hubungan satu arah antara solvabilitas dan audit delay, semakin tinggi solvabilitas maka jangka waktu audit delay semakin lama.

\subsubsection{Koefisien Determinasi $\left(\mathbf{R}^{2}\right)$}

Koefisien determinasi $\left(\mathrm{R}^{2}\right)$ merupakan bagian dari uji regresi linear berganda. Koefisien determinasi bertujuan untuk mengukur seberapa jauh kemampuan model dalam menerangkan variasi variabel dependen. Semakin tinggi nilai koefisien determinasi maka semakin tinggi kemapuan variabel independen dalam menjalaskan variasi variabel dependen. Cara melihat seberapa besar koefisien determinasi yaitu dengan melihat nilai Adjusted $\mathrm{R}^{2}$, karena dalam penelitian ini digunakan tiga variabel independen. Dari hasil uji regresi linear berganda diperoleh hasil sebagai berikut.

\begin{tabular}{l|l|r|r|c|}
\hline Model & $\mathrm{R}$ & $\mathrm{R}$ Square & $\begin{array}{c}\text { Adjusted R } \\
\text { Square }\end{array}$ & $\begin{array}{c}\text { Std. Error of the } \\
\text { Estimate }\end{array}$ \\
\hline 1 & $.494^{\mathrm{a}}$ & .244 & .178 & 16.03130 \\
\hline
\end{tabular}

(Sumber: Data hasil olahan SPSS, 2018)

Dari hasil uji regresi linear berganda, diperoleh koefisien determinasi memiliki nilai adjusted yaitu sebesar 0,178. Jadi kemampuan variabel independen yaitu ukuran perusahaan, profitabilitas, dan solvabilitas dalam menjelaskan variasi dari variabel dependen yaitu audit delay sebesar $17,8 \%$ sedangkan sisanya sebesar $82,2 \%$ dijelaskan oleh faktorfaktor lain yang tidak diikut sertakan dalam penelitian ini.

\subsubsection{Uji Hipotesis}

a. Uji t (Uji Parsial)

Uji t diilakukan untuk menguji signifikansi dari pengaruh masing-masing variabel independen terhadap variabel dependen. Tingkat signifikansi dalam penelitian ini yaitu 0,05 dengan pengujian dua arah (2-tailed) dan nilai t-tabel untuk $n=38$ dan $k=4$ maka $d f=34$ yaitu 2,032. Dari hasil uji regresi linear berganda diperoleh hasil sebagai berikut.

Coefficients $^{\mathrm{a}}$

\begin{tabular}{|c|c|c|c|c|c|c|}
\hline \multirow{2}{*}{\multicolumn{2}{|c|}{ Model }} & \multicolumn{2}{|c|}{ Unstandardized Coefficients } & \multirow{2}{*}{$\begin{array}{c}\begin{array}{c}\text { Standardized } \\
\text { Coefficients }\end{array} \\
\text { Beta }\end{array}$} & \multirow[b]{2}{*}{$t$} & \multirow[b]{2}{*}{ Sig. } \\
\hline & & B & Std. Error & & & \\
\hline \multirow[t]{4}{*}{1} & (Constant) & 57.883 & 29.733 & & 1.947 & .060 \\
\hline & UKURAN PERUSAHAAN & .937 & 1.024 & .139 & .915 & .366 \\
\hline & PROFITABILITAS & -1.727 & .548 & -.472 & -3.153 & .003 \\
\hline & SOLVABILITAS & .169 & .184 & .140 & .919 & .365 \\
\hline
\end{tabular}

a. Dependent Variable: AUDIT DELAY

(Sumber: Data hasil olahan SPSS, 2018)

Berdasarkan hasil analisis regresi secara parsial, maka diperoleh ukuran perusahaan memiliki nilai t-hitung sebesar $0,915<2,032$ dan nilai signifikansi $0,366>0,05$, profitabilitas memiliki nilai t-hitung sebesar 3,153>2,032 dan nilai signifikansi $0,003<$ 0,05 , dan solvabiliats memiliki nilai t-hitung sebesar $1,919<2,032$ dan nilai signifikansi $0,365>0,05$. Jadi dapat disimpulkan bahwa ukuran perusahaan tidak berpengaruh signifikan terhadap audit delay maka H1 ditolak karena t-hitung < t-tabel dan tingkat signifikansi > 
0,05, profitabilitas berpengaruh signifikan terhadap audit delay maka $\mathrm{H} 2$ diterima karena $\mathrm{t}$ hitung $>$ t-tabel dan tingkat signifikansi $<0,05$, dan solvabilitas tidak berpengaruh signifikan terhadap audit delay maka H3 ditolak karena t-hitung < t-tabel dan tingkat signifikansi > 0,05 .

b. Uji F (Uji Simultan)

Uji F diilakukan untuk menguji signifikansi dari pengaruh semua variabel independen terhadap variabel dependen. Tingkat signifikansi dalam penelitian ini yaitu 0,05 dengan pengujian dua arah (2-tailed) dan nilai F-tabel untuk $n=38$ dan $\mathrm{k}=4$ maka $\mathrm{df}=34$ yaitu 2,620. Dari hasil uji regresi linear berganda diperoleh hasil sebagai berikut.

ANOVA $^{\mathrm{a}}$

\begin{tabular}{|l|r|r|r|r|r|}
\hline \multicolumn{1}{|c|}{ Model } & Sum of Squares & Df & Mean Square & F & Sig. \\
\hline Regression & 2824.510 & 3 & 941.503 & 3.663 & $.022^{\text {D }}$ \\
Residual & 8738.084 & 34 & 257.002 & & \\
Total & 11562.595 & 37 & & & \\
\hline
\end{tabular}

a. Dependent Variable: AUDIT DELAY

b. Predictors: (Constant), SOLVABILITAS, PROFITABILITAS, UKURAN PERUSAHAAN

(Sumber: Data hasil olahan SPSS, 2018)

Berdasarkan hasil analisis regresi secara simultan, maka diperoleh nilai F-hitung sebesar 3,663 > 2,620 dan nilai signifikansi 0,022 < 0,05. Jadi dapat disimpulkan bahwa ukuran perusahaan, profitabilitas, dan solvabilitas berpengaruh signifikan terhadap audit delay maka H4 diterima karena F-hitung > F-tabel dan tingkat signifikansi $<0,05$.

\subsection{Pembahasan}

a. Pengaruh Ukuran Perusahaan terhadap Audit Delay

Berdasarkan hasil pengujian yang dilakukan diketahui bahwa ukuran perusahaan tidak berpengaruh signifikan terhadap audit delay, ukuran perusahaan memiliki nilai t-hitung sebesar 0,915 <2,032dan nilai signifikansi 0,366 > 0,05. Dengan demikian H1 ditolak sesuai dengan hasil uji hipotesis parsial (uji t). Ukuran perusahaan mempunyai hubungan searah atau positif terhadap audit delay, dimana semakin besar ukuran perusahaan maka audit delay semakin bertambah. Hasil penelitian ini dikhususkan pada objek penelitian perusahaan property dan real estate yang terdaftar di Bursa Efek Indonesia periode 2012 sampai dengan 2016.

Semakin besar ukuran perusahaan diperkirakan manjemen perusahaan semakin baik. Pengaruh yang tidak signifikan dari ukuran perusahaan terhadap audit delay, disebabkan adanya penggunaan sampel dalam penelitian ini yang menggunakan keseluruhan perusahaan property dan real estate yang terdaftar di Bursa Efek Indonesia sehingga memiliki kesamaan dalam hal pengawasan dari pihak investor dan masyarakat umum, maka hal ini memungkinkan bahwa perusahaan besar maupun kecil memiliki manajemen yang baik dan memiliki kemampuan untuk menekan auditornya agar dapat menyelesaikan pekerjaan audit secara tepat waktu. Perusahaan property dan real estate yang memiliki nilai aset besar maupun kecil memiliki audit delay yang tidak berbeda jauh, ini menunjukan setiap perusahaan mampu menyeimbangkan internal kontrol sehingga berdampak terhadap waktu penyelesaian audit.

b. Pengaruh Profitabilitas terhadap Audit Delay

Berdasarkan hasil pengujian yang dilakukan diketahui bahwa profitabilitas berpengaruh signifikan terhadap audit delay, profitabilitas memiliki nilai t-hitung sebesar $3,153>2,032$ dan nilai signifikansi $0,003<0,05$. Dengan demikian H2 diterima sesuai dengan hasil uji hipotesis parsial (uji t). Profitabilitas mempunyai hubungan berlawanan arah atau negatif terhadap audit delay, dimana semakin besar profitabilitas maka audit delay semakin berkurang. Hasil penelitian ini dikhususkan pada objek penelitian perusahaan property dan real estate yang terdaftar di Bursa Efek Indonesia periode 2012 sampai dengan 2016. 
Perusahaan yang memiliki laba semakin besar memiliki kemampuan untuk membayar audit fee yang lebih tinggi, sehingga perusahaan dapat menentukan Kantor Akuntan Publik (KAP) yang dapat melakukan penyelesaian audit lebih cepat. Selain itu perusahaan yang mengalami tingkat profitabilitas tinggi (good news) cenderung mengharapkan penyelesaian audit secepat mungkin dan tidak akan menunda penerbitan laporan keuangan mereka. Dengan demikian, perusahaan yang memperoleh good news cenderung akan lebih cepat dalam penyampaian laporan keuangan dibandingkan dengan perusahaan yang memperoleh profitabilitas yang rendah ataupun mengalami kerugian.

c. Pengaruh Solvabilitas terhadap Audit Delay

Berdasarkan hasil pengujian yang dilakukan diketahui bahwa solvabilitas tidak berpengaruh signifikan terhadap audit delay, solvabiliats memiliki nilai t-hitung sebesar 1,919<2,032 dan nilai signifikansi 0,365 > 0,05. Dengan demikian H3 ditolak sesuai dengan hasil uji hipotesis parsial (uji t). Solvabilitas mempunyai hubungan searah atau positif terhadap audit delay, dimana semakin besar ukuran perusahaan maka audit delay semakin bertambah. Hasil penelitian ini dikhususkan pada objek penelitian perusahaan property dan real estate yang terdaftar di Bursa Efek Indonesia periode 2012 sampai dengan 2016.

Solvabilitas merupakan salah satu rasio untuk menunjukan kesehatan keuangan perusahaan, namun bukan penentu apakah kinerja perusahaan dinilai baik atau tidak, karena ketika perusahaan mampu memperoleh laba yang tinggi perusahaan mampu untuk membayar hutangnya. Tingkat hutang perusahaan yang tinggi cenderung membutuhkan waktu audit yang lama, namun apabila tidak terjadi kesalahan atau kecurangan terhadap pencatatan hutang perusahaan, maka tidak perlu dilakukan audit secara menyeluruh yang akan berdampak terhadap audit delay. Perusahaan property dan real estate yang menjadi objek dalam penelitian ini menurut hasil dokumentasi laporan audit, tidak terdapat permasalahan dalam pencatatan hutang perusahaan, sehingga perusahaan yang memiliki solvabilitas yang tinggi maupun rendah mempunyai audit delay yang tidak berbeda jauh.

d. Pengaruh Ukuran Perusahaan, Profitabilitas, dan Solvabilitas terhadap Audit Delay

Berdasarkan hasil pengujian yang dilakukan diketahui bahwa ukuran perusahaan, profitabilitas, dan solvabilitas berpengaruh signifikan terhadap audit delay dengan nilai Fhitung sebesar 3,663 > 2,620 dan nilai signifikansi 0,022 < 0,05. Dengan demikian H4 diterima sesuai dengan hasil uji hipotesis simultan (uji F). Hasil penelitian ini dikhususkan pada objek penelitian perusahaan property dan real estate yang terdaftar di Bursa Efek Indonesia periode 2012 sampai dengan 2016.

\section{KESIMPULAN DAN SARAN \\ 5.1. Kesimpulan}

1. Ukuran perusahaan tidak berpengaruh signifikan terhadap audit delay dengan nilai thitung sebesar $0,915<2,032$ dan nilai signifikansi $0,366>0,05$ serta mempunyai hubungan positif terhadap audit delay dengan nilai koefisien regresi $\left(\beta_{1}\right)$ sebesar 0,915 .

2. Profitabilitas berpengaruh signifikan terhadap audit delay dengan nilai t-hitung sebesar 3,153 > 2,032 dan nilai signifikansi $0,003<0,05$ serta memiliki hubungan negatif terhadap audit delay dengan nilai koefisien regresi $\left(\beta_{2}\right)$ sebesar $-3,153$.

3. Solvabilitas tidak berpengaruh signifikan terhadap audit delay dengan nilai t-hitung sebesar $1,919<2,032$ dan nilai signifikansi 0,365>0,05 serta memiliki hubungan positif terhadap audit delay dengan nilai koefisien regresi $\left(\beta_{3}\right)$ sebesar 0,919 .

4. Ukuran perusahaan, profitabilitas, dan solvabilitas berpengaruh signifikan terhadap audit delay dengan nilai F-hitung sebesar 3,663 > 2,620 dan nilai signifikansi 0,022 < 0,05 serta memiliki nilai koefisien determinasi $0,178(17,8 \%)$. 


\subsection{Saran}

1. Untuk perusahaan go public, harus mempublikasikan data laporan keuangan tahunan setiap tahunnya dengan lengkap, agar data yang diperoleh dapat memberikan gambaran kondisi perusahaan dengan tepat sesuai dengan kebutuhan pemakai laporan keuangan. Perusahaan diharapkan mampu bertanggung jawab dan menaati aturan yang sudah ditetapkan.

2. Untuk investor, sebaiknya mencari tahu mengenai data keuangan perusahaan sebaikbaiknya, dalam membuat pertimbangan atau prediksi yang akurat untuk menetapkan keputusan investasi. Investor juga harus lebih teliti dalam memperhatikan rasio-rasio keuangan yang mencerminkan kinerja keuangan perusahaan di masa depan.

3. Untuk auditor, agar dapat melakukan pekerjaan lapangan dengan sebaik-baiknya sehingga pekerjaan dapat dilakukan secara efektif dan efisien sehingga auditor dapat mengeluarkan laporan audit yang sesuai dengan prosedur dan tepat waktu.

4. Untuk penelitian selanjutnya, diharapkan dapat meneliti lebih dalam tidak hanya terbatas pada variabel yang telah diteliti dalam penelitian ini, melainkan perlu adanya penambahan variabel lainnya serta diharapkan dapat menggunakan cakupan objek penelitian yang lebih luas. Selain itu, data penelitian harus lengkap sesuai dengan objek yang ditetapkan.

\section{DAFTAR PUSTAKA}

Apriliane, Dwi Malinda. 2015. Analisis Faktor-Faktor yang Mempengaruhi Audit Delay (Studi Empiris Pada Perusahaan Pertambangan yang Terdaftar di Bursa Efek Indonesia Tahun 2008 - 2013). Thesis, Fakultas Ekonomi. Universitas Negeri Yogyakarta.

Apriyana, Nurahman. 2017. Pengaruh Profitabilitas, Solvabilitas, Ukuran Perusahaan, dan Ukuran Kap Terhadap Audit Delay Pada Perusahaan Properti dan Real Estate yang Terdaftar di Bursa Efek Indonesia Periode 2013-2015. Jurnal Nominal Vol. VI No. 2. Yogyakarta. Akuntansi Universitas Negeri Yogyakarta.

Ardianti, Fanie. 2013. Analisis Faktor-FAktor yang Berpengaruh Terhadap Audit Delay (Studi pada Perusahaan Manufaktur yang Terdaftar di Bursa Efek Indonesia). Skripsi. Semarang. Fakultas Ekonomika dan Bisnis Universitas Diponegoro.

Ashton, R., Wilingham, J., \& Elliot, R. 1987. An Empirical Analysis of Audit Delay. Journal of Accounting Research, Vol. 25, No. 2, 275-292.

Dyer, J.C. and McHugh, A.L. 1975. The Timeliness of The Australian Annual Report. Journal of Accouting Research. Auntum, pp204-219.

Fahmi, Irham. 2014. Analisis Laporan Keuangan. Bandung: Alfabeta.

Ferry, M. G and Jones, W. H. 1979. Determinats Of Financial Structure A New Methhodological Approach. The Journal of Financial Vol. XXXIV, No. 3.

Kasmir. 2016. Analisis Laporan Keuangan. Jakarta: Raja Grafindo Persada.

Lawrence, J, dan B. Bryan. 1998. Characteristics Associated with Audit Delay in The Monitoring Of Low Income Housing Projects. Journal of Public Budgeting, Accounting \& Financial Management. 10(2): 173-191.

Prameswari, Afina Survita dan Yustrianthe, Rahmawati Hanny. 2015. "Analisis Faktor Faktor yang Memengaruhi. Audit Delay (Studi Empiris Pada Perusahaan Manufaktur Yang Terdaftar di Bursa Efek Indonesia”. Jurnal Akuntansi/ Volume XIX, Nomer 01. Sekolah Tinggi Ilmu Ekonomi YAI Jakarta.

Wardan, Lista dan Mushawir. 2016. “Analisis Faktor-Faktor Yang Mempengaruhi Audit Delay (Studi Empiris Pada Perusahaan Yang Terdaftar Sebagai Anggota LQ45 Di BEI Periode 2010-2015)”. JRAMB Volume 2 No. 2. Prodi Akuntansi, Fakultas Ekonomi, UMB. Yogyakarta. 